\title{
Currency Valuation and Purchasing Power Parity
}

Jamal Ibrahim Haidar

\section{Introduction}

The analytical framework of currency valuation is an intellectual challenge and of influence to economic policy, the smooth functioning of financial markets and the financial management of many international companies. The Economist magazine argues that its Big Mac Index (BMI), based on the price of a Big Mac hamburger across the world, can provide 'true value' of currencies. This paper provides ten reasons for why the BMI cannot provide a 'true' value of currency, and it proposes adjustments to specific misalignments.

The purchasing power parity (PPP) theory postulates that national price levels should be equal when expressed in a common currency. Since the real exchange rate is the nominal exchange rate adjusted for relative national price levels, variations in the real exchange rate represent deviations from PPP. It has become something of a stylised fact that the PPP does not hold continuously. British prices increased relative to those in the US over the past 30 years, while those of Japan decreased. According to PPP theory, the British pound should have depreciated (an increase in the pound cost of the dollar) and the Japanese yen should have appreciated. This is what in fact happened. Despite deviations in the exchange rate from price ratios, there is a distinct tendency for these ratios to act as

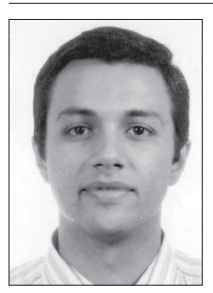

Jamal Ibrahim

Haidar is a

consultant in the

International

Finance

Corporation of the

World Bank. 
Despite deviations in the exchange rate from price ratios, there is a distinct tendency for these ratios to act as anchors for exchange rates. anchors for exchange rates. Thus, exchange rate reverts to the price ratio, which can be considered the 'true value' of the currency.

In 1986, The Economist created a tool for making PPP comparisons. This tool uses the price of a

Big Mac hamburger at home and abroad as the price ratio that reflects the 'true value' of the currency. This ratio represents the BMI; it is the nucleus of 'burgernomics'. The BMI gives a signal about under-valuation and over-valuation of currencies, relative to the actual exchange rate. The PPP school of thought is among the oldest research areas in international finance. The PPP stands as a general form of the law of one price in the geographical arbitrage presence for the same goods at different location. The PPP holds only within strict circumstances - i.e. lack of central bank interventions, trade restrictions, transaction costs and taxes. A reference to PPP helps determine whether the foreign exchange market precisely prices a currency because a currency, typically, reverts to its PPP value over time. The BMI currency pricing model is well embedded in the PPP theory. It is a case of interaction between financial journalism, basic economic research and foreign exchange markets.

This paper uses the occasion of the 25th anniversary of the introduction of the Big Mac Index to provide a broad evaluation of its workings

and performance. While the BMI is not perfect, it provides hints about the operation of foreign exchange markets. The second part of the paper provides a literature review of 'burgernomics', presents evidence about the BMI and summarises the PPP theory debate. After that, there is a discussion of a set of BMI methodological limitations, and clarification of the BMI bias. The paper ends with a conclusion section.

\section{Evidence to date}

The literature on PPP is large and growing. Froot and Rogoff (1995), Lan and Ong (2003), Rogoff (1996), Sarno and Taylor (2002), Taylor and Taylor (2004) and Taylor (2006) are a subset of available literature reviews on the matter. Click (1996), Ong (1997), and Pakko and Pollard (1996) are among the early contributors to academic research on the 
BMI, while more recent papers include Chen et al. (2007) and Clements et al. (2010). Empirically, studies found heterogeneous results while testing PPP. Frankel (1979) studied the correlation between exchange rates and inflation (proxied by CPI and then by WPI) ${ }^{1}$ in the 1920 s, finding PPP-supportive results in hyperinflation economies. However, using the same inflation indicators, the same author, among others (Isard 1977; Frankel 1981), rejects PPP for developed countries during the 1970s. Nonetheless, inflation and exchange rate non-stationarity invalidates these findings by showing the shortcomings of conventional testing methods. Meanwhile, more recent research (Wu \& Chen 1999; Pedroni 2004) has rejected PPP validity (i.e. real exchange rate mean reversion) by utilising cross-country datasets, while Frankel and Rose (1996) empirically validated PPP existence.

The above studies, which use CPI or WPI, have at least two shortcomings. First, non-tradable goods affect CPI and WPI relative usage across countries. Second, regardless of whether the law of one price holds in a certain market for a specific commodity, CPIs and WPIs behave differently when consumption bundles are not identical, leading to PPP tests' biased outcomes. Hence, these price indices can lead to heterogeneous results while testing PPP validity. Recent studies have shifted their attention to using another price index as a study target. Cumby (1996) used The Economist's BMI, given its uniform composition feature, as the Big Mac ingredients are identical across countries, to assess PPP. The use of the Big Mac decreases the estimation bias given that it meets the 'identical good' requirement in the law of one price testing process. However, it does not meet all the requirements of the law of one price - i.e. barriers to trade, wage rate, taxes and productivity differentials.

\section{Methodological limitations of the BMI}

\section{Demand variability}

The demand for fast food varies across countries. For instance, the North American relationship with the Big Mac is much more ingrained into culture than it is in Asian cultures. For this reason, a direct comparison using the Big Mac Index (BMI) has some problems. First, food regulations differ

1 The study considered PPP valid when the regression coefficient is 1 . 
across countries. For example, Switzerland and the euro area have much more strict food regulation laws (Switzerland in particular) than the United States. This means that the cost of 'better' beef or other parts of a Big Mac is higher in the euro area. Second, there is the social perception and price

In Ukraine, one of the places to meet and relax is McDonald's. differential of McDonald's in the different countries. In Switzerland and much of Europe, McDonald's is more of a 'nice' place. It is not

surprising for McDonald's in Europe to have multiple storeys and in Switzerland there are video game systems and lounges. In Ukraine, one of the places to meet and relax is McDonald's. This means that, in general, the outlets are located in better places and have higher rent payments in Europe. Also, richer people visit McDonald's in Switzerland and the euro area, and will continue to pay for such goods despite the price. In the United States, however, McDonald's is typically a cheaper place to eat and restaurants would lose a lot more money by increasing prices than in European McDonald's outlets. With such variations, the BMI perpetuates a false idea that a critical analyst can discover anything at all about PPP by comparing hamburgers.

\section{Product comparability}

The theory of purchasing power parity (PPP), the notion that a dollar should buy the same amount in all countries, implies that, in the long term, the exchange rate between two countries should move towards the rate that equalises the prices of an identical basket of goods and services in each country. However, the United States, along with most developed economies, subsidises meat, bread (which is made of wheat), lettuce, tomato, eggs, potatoes and all farm products in a Big Mac burger. Also, these countries exercise protectionism on those products as well as adopt a mercantilist approach in the international market. So, how can a Big Mac be a comparable item? For any product to be useful for that purpose, it should be freely tradable between countries, with no country subsidising or taxing it more than another country. Therefore, the Big Mac is less appropriate as an item for price comparison since it would be cheaper in countries that subsidise farm products - and this may lead to a distorted comparison. 


\section{Exchange rate predictability}

A 'weak' currency, despite its appeal to exporters and politicians, is no free lunch - but it can provide a cheap one. In China, for example, a McDonald's Big Mac costs just 14.5 yuan on average in Beijing and Shenzhen, the equivalent of $\$ 2.18$ at market exchange rates. In the US, in contrast, the same burger costs, on average, $\$ 3.71$. A difference of this significance makes China's yuan one of the most undervalued currencies in the most recent BMI, leading to currency misalignments. Since the BMI is based on the idea of PPP, and 14.5 yuan can buy as much burger as $\$ 3.71$, a yuan should be worth $\$ 0.26$ on the foreign exchange market. In fact, it costs just $\$ 0.15$, suggesting that it is undervalued by about $40 \%$. In Brazil a Big Mac costs the equivalent of $\$ 5.26$, implying that the real is overvalued by $42 \%$. The index also suggests that the euro is overvalued by about $29 \%$. The Swiss franc is the most expensive currency, according to the BMI list. Japan is so far the only rich country to intervene directly in foreign exchange markets to weaken its currency. But, according to the BMI, the yen is only $5 \%$ overvalued.

How can The Economist justify this misalignment? It should perhaps rely not on Big Macs, but on three less digestible approaches. First, it can calculate the real exchange rate that would steadily bring a country's current account balance (equivalent to the trade balance plus a few other things) into line with a 'norm' based on the country's growth, income per person, demography and budget balance. Second, it can ignore current account balances and instead calculate a direct statistical relationship between the real exchange rate and things like a country's terms of trade (the price of its exports compared with its imports), its productivity and its foreign assets and liabilities. The strength of Brazil's currency, for example, may partly reflect the high price of exports such as soya beans. Third, it can also calculate the exchange rate that would stabilise the country's foreign assets and liabilities at a reasonable level. If, for example, a country runs sizeable trade surpluses, resulting in a rapid build-up of foreign assets, it probably has an undervalued exchange rate. Indeed, the raw index did a poor job of predicting exchange rates: undervalued currencies remain too cheap and overvalued currencies remain too expensive. Such misalignments are remarkably persistent. They give a signal of a systematic bias showing that the BMI may itself be undervalued. 


\section{Elements non-tradability}

The Big Mac Index does have other shortcomings. A Big Mac's price reflects more than just the cost of bread, meat and vegetables. It also reflects non-tradable elements such as rent and labour. For that reason, the $\mathrm{BMI}$ is probably best when comparing countries at roughly the same stage of development. In any case, there is no theoretical reason why prices of non-tradable goods and services should be equal in different countries. This explains why PPPs are different from market exchange. The BMI is an interesting way to get a snapshot of comparative countries and their exchange rates. However, domestic prices (inflation) and the local domestic economy also play a role in determining the prices.

In the absence of trade barriers, the dollar price of a certain good should be identical across countries, according to PPP theory. Given that the price of a Big Mac captures more than the (tradable) components cost - i.e. restaurant space lease, heating and cooling utilities, electricity costs and wages - the price of the good would be expected to be different across countries. These are non-tradable goods examples. For instance, the location of the property cannot be traded, although the property itself can be traded and transferred between owners. Also, the use of labour is a non-tradable good given labour restrictions with regard to moving across borders to benefit from wage differentials. Thus, although the price of a restaurant's rent space is lower in Sofia than in Paris, it would not be feasible to do so if the purpose is to serve meals in Paris. Rent and utilities contribute to the cost (and price) of a Big Mac, causing deviations from PPP by reflecting cost differences across countries. Non-tradable goods represent $94 \%$ of the Big Mac price (Ong 1997). The Big Mac provides evidence about why systematic deviations from PPP exist.

The next section considers an explanation of a key PPP failure: the existence of barriers to trade. The PPP does not hold, at minimum in absolute terms, partly because of the high cost of trading goods across borders. Limitations on the international movement of goods include tariffs, export taxes, transportation costs, and other government-imposed trade barriers, which contribute to price differentials.

\section{Transportation costs}

Although the cost of transporting the corn oil needed for the Big Mac may not be high, transporting perishable components such as beef, cheese and 
lettuce is more costly. Thus, transportation costs may drive the price differential for same good across markets. In 2002, a Big Mac cost \$2.38 in the euro area, 11 cents less than the price in the US. Although such a price differential may violate PPP, Big Macs' (or Big Mac components') transportation across borders may not necessarily occur. In theory, trade may occur, in this case, conditional on whether the Big Mac transportation cost is less than 11 cents. Hence, one might expect absolute PPP to hold only approximately, with prices diverging within a range determined by the transport costs. ${ }^{2}$

\section{Trade restrictions}

Using tariffs while practising protectionism, countries impose import restrictions, for instance, on farm products to protect certain industries. The presence of tariffs on imported goods and import quotas constitutes another significant factor of trade restrictions. Cassel (1921) studied the effects of trade restrictions, stating, 'If trade between two countries is more hampered in one direction than in the other, the value of the money of the country whose export is relatively more restricted will fall, in the other country, beneath the purchasing power parity.' The author noted that export and import restrictions have opposite effects on PPP. In monetary terms, on a PPP basis, the economies with fewer restrictions on imports will have relatively undervalued currencies. In simpler language, the BMI would be informative in terms of which economies impose more restrictions on agricultural products trade, assuming no other PPP deviation drivers, compared to the US. For instance, among the countries that imposed high import tariffs on beef during the BMI's life are Korea and Japan. Beef imports to Japan, until 1991, were subject to quotas and tariffs. In addition, tariffication ${ }^{3}$ came into place in Japan during 1991 and in Korea during 1995. On a related side, Korea imposed a $30 \%$ tariff on beef imports for five years up to 1994, along with other trade barriers. It cancelled the import quota and set the tariff rate at $41 \%$ in 2001, allowing it to decrease to $40 \%$ by 2004 . A key driver of the beef price differential between Japan and Korea, and other countries, in this case, is factored by such trade barriers, which provide partial reasoning, as well, to the Japanese yen and the

\footnotetext{
${ }^{2}$ Hummels (2001) estimates that transportation costs add $7 \%$ to the price of US imports of meat, $6 \%$ to the import price of dairy products, and $16 \%$ to the import price of vegetables.

3 Tariffication is an effort to convert existing agricultural non-tariff barriers to trade (NTBs) into bound tariffs and to reduce these tariffs over time. A bound tariff is one that has a 'ceiling' beyond which it cannot be increased.
} 
Korean won overvaluation against the dollar until the late 1990s. However, the US also restricts the volume of beef imports from all countries apart from Canada and Mexico. ${ }^{4}$ In April 2002, McDonald's began buying some imported beef from Australia and New Zealand for its US operations. The quota, however, limits the extent to which McDonald's can use imported beef to offset hamburger price pressures. In addition, the higher barriers to trade in beef in the US may partly explain why the US dollar has been consistently overvalued relative to the Australian and New Zealand dollars. In a nutshell, compared to the US, economies with fewer trade restrictions would be expected to be associated with undervalued currencies.

\section{Taxes}

The existence of different taxation schemes across countries contributes to PPP deviations. The Economist BMI uses sales and VAT (value added taxes) tax-inclusive prices. Thus, ceteris peribus, higher taxes would be associated with overvalued currencies on the BMI. Simultaneously, tax adjustments would lead to BMI parities shifts. For example, in 1991 Canada imposed the Goods and Services Tax, a national $7 \%$ sales tax. Between 1990 and 1991, the price of a Big Mac rose from C\$2.19 to $\mathrm{C} \$ 2.35$. As a result, the Canadian dollar moved from being undervalued by $14 \%$ against the US dollar to being undervalued by only $9 \%$. It would be misleading, however, to say that the imposition of this new tax brought the US and Canada closer to PPP.

\section{Productivity differentials}

The BMI and other price indices include non-tradables. Samuelson (1964) and Balassa (1964) proved that non-traded goods systematically influence PPP deviations due to productivity differences across countries, industries and sectors. They also showed that low-income countries will have undervalued currencies compared to high-income countries, assuming that economies with higher GDP per capita levels reflect, to a certain extent, higher labour productivity.

Moreover, given competition for workers in each of non-traded and traded goods sectors, wages are higher in high-income economies, which are associated with more labour productivity in traded goods sectors.

${ }^{4}$ Imports beyond the quota limit face a $26.4 \%$ tariff rate. 
Wages in the service sector are lower in low-income economies, leading to lower prices in low-income economies. Regardless of whether prices of traded goods are identical across countries, lower service prices transmit to lower price levels in low-income economies. In different terms, the currencies of low-income economies would appear undervalued compared to the currencies of highincome economies. Turning to Big Macs, it is unlikely that there are large differences in the productivity of workers cooking burgers regardless of the country of location of the

It is unlikely that there are large differences in the productivity of workers cooking burgers regardless of the country of location of the McDonald's. There are, however, large differences in the wages earned by these workers.

McDonald's. There are, however, large differences in the wages earned by these workers. This difference in wage costs may partly explain why the yuan and the zloty have been consistently undervalued against the dollar as measured by BMI. In fact, according to the Balassa-Samuelson theory, holding all other things constant the dollar should be overvalued against the currencies of low-income countries.

\section{Government expenditures and current account deficits}

Differences in government expenditures across economies may lead to relative prices deviations from exchange rates. Governments spend less on traded goods than does the private sector (households and businesses). When government spending, for instance, in the United States decreased compared to government spending in other countries, the price of nontraded goods in the United States will decrease as will the overall price level. Another role for non-traded goods in explaining deviations from PPP comes through the current account. Krugman (1990) argued that, as a country runs a current account deficit, its spending on traded goods increases relative to other countries. This argument results in a decline in the relative price of non-tradable goods in the deficit country. Thus, if PPP had held prior to the current account deficit, the country's currency would then be undervalued.

\section{Pricing to market}

Firms can optimise profits by charging different prices across countries when they are capable of pricing to market depending on product demand 
elasticity. When demand for a good is inelastic (elastic), prices and sales revenues are positively (negatively) associated. At the same time, firms that price to market across countries or markets may limit exchange rate pass-through - the extent to which changes in the exchange rate result in changes in import prices.

When imports prices do not change exactly according to foreign currency valuation patterns, then exchange rate pass-through is incomplete, leading to a price differential between domestic and foreign markets. In order to sustain relative sales and profit margin levels when currency value changes, a firm may control pass-through in markets where demand is relatively elastic. Certain factors shape firms' ability to price to market - i.e. warranty restrictions, the resale probability across markets, business regulations, safety standards, wholesalers' authorisations and pollution criteria. In the case of the Big Mac, obviously, unlike its ingredients, it is not subject to resale across markets. While ingredients can be purchased to create a competing sandwich, in many countries there are few substitutes to the Big Mac sandwich, unlike the case in the US. Thus, it is reasonable to conclude that the Big Mac is not all about the ingredients. Other factors, including people's interests, shape the Big Mac demand curve - and such factors also shape the pricing-to-market strategies. For instance, while young Koreans perceive McDonald's as a fancy place to hang out, their peers in the US perceive it as no more than a low-priced fast-food destination.

\section{Conclusion}

The Economist magazine has been publishing its Big Mac Index for the past quarter of a century. The purpose of the indicator, according to The Economist, is to show 'real valuation' of currencies, mainly by assuming that PPP theory holds. This paper shows why the BMI fares poorly as a valuation tool as well as a forecasting mechanism. It presents various angles of the PPP theory and highlights how each of them reduces the effectiveness of one-product currency valuations indicators such as the BMI. Various studies have assessed the validity of PPP theory by using different inflation measures across countries. This paper adds to the literature by showing, using PPP theory framework, why The Economist's BMI currency valuation indicator should be perceived with caution, by highlighting its characteristics from tradable commodities and non- 
tradable service components. It clarifies that the BMI can actually be perceived as a good example of how, when and why the PPP does not hold. Prices differ across countries for reasons not related to the value of currency. For instance, even the price of one product (i.e. the Big Mac sandwich) is not constant within the same country (i.e. the US). In this case, the BMI says that the value of dollar, compared to other countries, is not the same across two different areas in the US. This observation is hard to digest as a credible currency valuation mechanism. Future research can look further at the contributions of country borders to PPP deviations.

\section{References}

Balassa, B. (1964) The purchasing power parity doctrine: a reappraisal. Journal of Political Economy, 72, 6, pp. 584-596.

Cassel, G. (1921) The World's Monetary Problems. London: Constable and Company.

Chen, C.-F., Shen, C.-H. \& Wang, C.-A. (2007) Does PPP hold for Big Mac price or consumer price index? Evidence from panel cointegration. Economics Bulletin, 6, 16, pp. $1-15$.

Clements, K.W., Lan, Y. \& Seah, S.P. (2010) The Big Mac Index two decades on an evaluation of burgernomics. Economics Discussion working papers 10-14. University of Western Australia, Department of Economics.

Click, R.W. (1996) Contrarian MacParity. Economics Letters, 53, 2, November, pp. 209 212.

Cumby, R.E. (1996) Forecasting exchange rates and relative prices with the hamburger standard: is what you want what you get with MacParity? NBER working paper 5675. National Bureau of Economic Research, Inc.

Frankel, J.A. (1979) On the mark: a theory of floating exchange rates based on real interest differentials. American Economic Review, 69, 4, September, pp. 610-622.

Frankel, J.A. (1981) Collapse of purchasing power parity during the 1970s. European Economics Revierw, 16, 1981a, pp. 145-165.

Frankel, J.A. \& Rose, A.K. (1996) A panel project on purchasing power parity: mean reversion within and between countries. Journal of International Economics, 40, 1-2, Elsevier, pp. 209-224. 


\section{Jamal Ibrahim Haidar}

Froot, K.A. \& Rogoff, K. (1995) Perspectives on PPP and long-run real exchange rates. In: Grossman, G. \& Rogoff, K. (eds) Handbook of International Economics. Volume 3. Amsterdam: North Holland Press.

Hummels, D. (2001) Time as a trade barrier, GTAP Working Papers 1152, Center for Global Trade Analysis, Department of Agricultural Economics, Purdue University.

Isard, P. (1977) How far can we push the 'law of one price'?. American Economic Review 67, 5, pp. 942-948.

Krugman, P.R. (1990) Equilibrium exchange rates. In: Branson, W.H., Frenkel, J.A. \& Goldstein, M. (eds) International Policy Coordination and Exchange Rate Fluctuations. Chicago: University of Chicago Press, pp. 159-187.

Lan, Y. \& Ong, L.L. (2003) The growing evidence on purchasing power parity. In: Ong, L.L. (ed.) The Big Mac Index: Applications of Purchasing Power Parity. UK: Palgrave Macmillan, pp. 29-50.

Ong, L.L. (1997) Burgernomics: the economics of the Big Mac Standard. Journal of International Money and Finance, 16, pp. 865-878.

Pakko, M.R. \& Pollard, P.S. (1996) For here or to go? Purchasing power parity and the Big Mac. Federal Reserve Bank of St Louis Review, 78, 1, January/February, pp. 3-22.

Pedroni P. (2004) Panel cointegration asymptotic and finite sample properties of pooled time series tests with an application to the PPP hypothesis. Ecomometric Theory, 20, pp. 597-625.

Rogoff, K. (1996) The purchasing power parity puzzle. Journal of Economic Literature, 34, 2, June, pp. 647-668.

Samuelson, P.A. (1964) Theoretical notes on trade problems. Review of Economics and Statistics, 46, 2, May, pp. 145-154.

Sarno, L. \& Taylor, M. (2002) Purchasing power parity and the real exchange rate. IMF Staff Papers, 49, pp. 65-105.

Taylor, A. \& Taylor, M.P. (2004) The purchasing power parity debate. Journal of Economic Perspectives, 18, pp. 135-158.

Taylor, M. (2006) Real exchange rates and purchasing power parity: mean reversion in economic thought. Applied Financial Economics, 16, pp. 1-17.

Wu, J-L. \& Chen, S-L. (1999) Are real exchange rates stationary based on panel unitroot tests? Evidence from Pacific Basin countries. International Journal of Finance $\mathbb{E}$ Economics, 4, 3, July, pp. 243-252. 